\title{
Aktivitas Antidiabetes Ekstrak Etanol Dillenia suffruticosa (Griff.) Martelli pada Tikus Diabetes yang Diinduksi Streptozotosin-Nikotinamid
}

\section{Antidiabetic Activity of Dillenia suffruticosa (Griff.) Martelli Ethanolic Extract in Streptozotocin-icotinamide-Induced Diabetic Rats}

\author{
Rico Hediyansah", Nurul Salima, Kristiando Siburian , Masriani, Rahmat Rasmawan \\ Chemistry Education Study Program, Faculty of Teacher Training and Education, \\ Tanjungpura University, Jl. Prof.Dr.H.Hadari Nawawi, Pontianak 78124, Indonesia \\ *Corresponding author email: ricohediansah1000@gmail.com
}

Received 28-10-2019 Accepted 12-12-2019 Available online 30-12-2019

\begin{abstract}
ABSTRAK
Tujuan penelitian ini adalah untuk mengetahui aktivitas antidiabetes ekstrak etanol kayu batang simpur (Dillenia suffruticosa (Griff.) Martelli dalam menurunkan kadar glukosa darah tikus diabetes yang diinduksi streptozotosin-nikotinamid (STZ-NA). Desain penelitian ini adalah Rancangan Acak Lengkap (RAL) dengan 6 kelompok $(N=30)$. Selain kelompok normal, semua kelompok diinduksi streptozotosin-nikotinamid $(45,110 \mathrm{mg} / \mathrm{kg}$ BB ) pada awal perlakuan. Ekstrak etanol kayu batang simpur diberikan secara intraperitoneal dengan dosis P1 (150 mg/kg BB), P2 (300 mg/kg BB) dan P3 (600 mg/kg $\mathrm{BB}$ ). Kelompok kontrol positif (KP) diberi glibenklamid 0,09 $\mathrm{mg} / 200 \mathrm{~g}$ dan kelompok kontrol negatif (KN) sebagai kelompok diabetes. Pengukuran glukosa darah dilakukan dengan spektrofotometer UV-Vis metode enzimatis GOD-PAP. Hasil penelitian ini menunjukkan bahwa ekstrak etanol kayu batang simpur dengan dosis $600 \mathrm{mg} / \mathrm{kg} \mathrm{BB}$ menurunkan secara nyata kadar glukosa darah tikus yang diinduksi streptozotosinnikotinamid yang sebanding dengan glibenklamid. Berdasarkan hasil penelitian ini maka ekstrak etanol kayu batang simpur diharapkan dapat menjadi alternatif pengobatan diabetes.
\end{abstract}

Kata kunci: diabetes mellitus, Dillenia suffruticosa (Griff.) Martelli, ekstrak etanol, nikotinamida streptozotosin.

\section{ABSTRACT}

The aim of this study was to determine the antidiabetic activity of ethanolic extract of shrubby simpoh (Dillenia suffruticosa (Griff.) Martelli) stemwoods in lowering blood glucose levels in streptozotocin-nicotinamide-induced diabetic rats. This study was conducted using a laboratory experimental design of Completely Randomized Design $(C R D)$, in which 30 rats were divided into six groups. Rats in all groups but the normal 
group were induced by streptozotocin-nicotinamide $(45.110 \mathrm{mg} / \mathrm{kg} \mathrm{BW})$ at the start of treatment. Ethanolic extract of shrubby simpoh stemwood was intraperitoneally administrated at doses of 150,300, and $600 \mathrm{mg} / \mathrm{kg}$ BW for each rat in P1, P2, and P3, respectively. Rats in the positive control group $(P C)$ were given $0.09 \mathrm{mg} / 200 \mathrm{~g}$ of glibenclamide, while those in the negative control group (NC) were used as the diabetic groups. Glucose measurements were carried out using the GOD-PAP enzymatic method utilizing a UV-Vis spectrophotometer. The results of this study indicated that the ethanolic extract of shrubby simpoh stemwood at a dose of $600 \mathrm{mg} / \mathrm{kg}$ BW significantly reducing the blood glucose levels of streptozotocin-nicotinamide-induced rats, which were comparable to that of glibenclamide. This research suggested that ethanolic of shrubby simpoh stemwood could be a good candidate to alternatively treat diabetes.

Key words: ethanolic extract, diabetes mellitus, Dillenia suffruticosa (Griff.), nicotinamide, streptozotocin.

\section{Pendahuluan}

Diabetes mellitus (DM) yang dikenal dengan sebutan penyakit kencing manis telah menjadi permasalahan kesehatan baik di negara maju maupun berkembang. Penderita penyakit DM di Indonesia menempati urutan kelima setelah India, Cina, Amerika, dan Brazil (IDF Atlas, 2011). Kerugian dari Gross Domestic Bruto yang dialami akibat diabetes diperkirakan mencapai 1,7 triliun dolar Amerika dari tahun 2010 sampai 2030 (WHO, 2016).

DM merupakan kelompok penyakit metabolisme yang ditandai dengan tingginya kadar glukosa dalam darah yang disebabkan oleh penurunan produksi insulin karena perubahan/kerusakan progresif struktur beta pankreas. Penurunan produksi insulin mengakibatkan penurunan permeabilitas sel terhadap glukosa, sehingga terjadi penumpukan glukosa dalam darah. Hiperglikemia menjadi penyebab utama komplikasi diabetik, seperti nefropati, neuropati, retinopati, dan gangguan kardiovaskuler (Singha et al., 2013).

Selama ini, suplai hormon insulin melalui suntik insulin dan pemberian obat oral antidiabetes adalah cara yang paling banyak digunakan oleh penderita DM untuk mengontrol kadar glukosa darah (Sukandar dkk, 2008). Insulin dan obat antidiabetes modern yang saat ini digunakan menghasilkan efek samping seperti hipoglikemia, asidosis laktat dan gangguan penyerapan vitamin B12, gangguan saluran pencernaan, hepatitis, sakit kepala, dan udema (Sukandar et al., 2008; Campbell, 2007). Berbagai ekstrak dari tumbuhan obat telah digunakan secara tradisional untuk mengobati diabetes secara global.

Penggunaan ekstrak tumbuhan lebih menguntungkan karena efek sampingnya relatif sedikit bahkan tidak memiliki efek samping (Gupta et al., 2008). Dengan demikian, ekstrak tumbuhan berpotensi dikembangkan sebagai antidiabetes yang lebih aman dan efektif. 
Salah satu sumber bahan alam yang memiliki aktivitas hipoglikemik dan potensial dikembangkan menjadi antidiabetes adalah tumbuhan simpur (Dillenia suffruticosa). Tumbuhan simpur merupakan tumbuhan liar yang banyak tumbuh di Kalimantan Barat. Tumbuhan ini banyak ditemukan di hutan rawa, hutan bakau, tepi sungai, bukit, dan pegunungan. Penelitian Muharini (2018), menunjukkan bahwa kayu batang simpur mengandung senyawa metabolit sekunder yang didominasi oleh golongan fenolik dan flavonoid dengan kandungan total fenolik (TPC) sebesar 236,17 $\pm 14,61$ mg EGA/g ekstrak dan kandungan total flavonoid (TFC) sebesar 12,06 $\pm 0,39 \mathrm{mg}$ ER/g ekstrak. Hasil penelitian juga menunjukkan bahwa flavonoid memiliki aktivitas antidiabetes melalui fungsinya sebagai antioksidan. Ekstrak etanol kayu batang simpur memiliki kemampuan menghambat enzim $\alpha$-glukosidase dan radikal bebas (Masriani, 2018). Antioksidan mampu mengikat radikal bebas sehingga dapat mengurangi stres oksidatif. Berkurangnya stres oksidatif dapat mengurangi resistensi insulin dan mencegah perkembangan disfungsi dan kerusakan sel $\beta$ pankreas (Song, 2005).

$$
\text { Sebagai tumbuhan yang }
$$

berpotensi antidiabetes, kemampuan ekstrak etanol kayu batang simpur dalam menurunkan kadar glukosa darah dan memperbaiki kerusakan sel beta pankreas belum diketahui. Oleh karena itu, perlu dilakukan penelitian tentang kemampuan ekstrak etanol kayu batang simpur dalam menurunkan kadar glukosa darah tikus.

\section{Metode Penelitian}

Hewan Model

Hewan model yang digunakan dalam penelitian ini adalah tikus (Rattus novergicus) jantan galur Wistar (170-205 g) yang diperoleh dari Laboratorium Pusat Studi Pangan dan Gizi, Universitas Gajah Mada, Yogyakarta. Tikus disiapkan dalam kandang individual dan diberikan diet minum serta pakan standar secara ad libitum. Penggunaan hewan model dalam penelitian ini telah memperoleh persetujuan dari komisi etik penelitian kesehatan Rumah Sakit Umum Daerah (RSUD) Dr. Moewardi Surakarta dengan Nomor: 625/V/HREC/2019, tanggal 10 Mei 2019.

\section{Ekstraksi Tumbuhan}

Sampel yang digunakan dalam penelitian ini diambil di daerah Pontianak Timur. Kayu batang simpur yang masih basah sebanyak $11,5 \mathrm{~kg}$ dicuci lalu ditiriskan, kemudian dikeringkan dengan cara dianginanginkan. Setelah kering, sampel dihaluskan menggunakan mesin lalu ditimbang sebanyak $6 \mathrm{~kg}$ serbuk kering kayu batang simpur untuk kemudian direndam menggunakan pelarut etanol $96 \%$ hasil destilasi selama $3 \times 72$ jam.

\section{Desain Penelitian}

Penelitian ini menggunakan post test only control group design. Pengelompokkan dan perlakuan hewan model menggunakan Rancangan Acak Lengkap (RAL), tikus dibagi menjadi 6 (enam) kelompok yang masing-masing terdiri dari 5 (lima) ekor tikus. Besar sampel dalam penelitian ini mengacu pada persamaan Federer: (t-1) $(n-1) \geq$ 
15, $\mathrm{t}$ adalah jumlah kelompok perlakuan sedangkan $\mathrm{n}$ adalah jumlah hewan model setiap kelompok. Pembagian kelompok sebagai berikut: kelompok normal (N), kelompok diabetes (kontrol Negatif/KN), kelompok diabetes dengan glibenklamid 0,09 mg/200 g (kontrol positif/KP), kelompok diabetes dengan ekstrak etanol kayu batang simpur dosis $150 \mathrm{mg} / \mathrm{kg}$ BB (P1), $300 \mathrm{mg} / \mathrm{kg}$ BB (P2), dan $600 \mathrm{mg} / \mathrm{kg}$ BB (P3). Perlakuan dilakukan selama 28 hari. Kadar glukosa darah diukur pada hari ke-0, 7, 14, 21, dan 28. Hari ke-28, tikus dibedah dan diambil darahnya untuk pengujian selanjutnya.

Teknik Pengumpulan Data

Pengumpulan data kadar glukosa darah dilakukan secara spektrofotometri UV-Vis dengan metode enzimatis GOD-PAP. Data kadar glukosa darah dikumpulkan melalui pengukuran kadar glukosa darah yang dilakukan pada hari ke-0, 7, 14, 21 dan 28. Pengukuran glukosa dengan metode enzimatis GODPAP (Glucose Oxidase-Phenol 4Aminoantipirin) dilakukan setelah oksidasi enzimatis oleh glukosa oksidase. Hidrogen peroksida yang terbentuk akan bereaksi dengan fenol dan 4aminophenazone menjadi kuinonemin (merah violet) oleh adanya enzim peroksidase (Rias, 2017).

Analisis Statistik

Data kadar glukosa darah dari lima ekor tikus di masing-masing kelompok diekspresikan dengan ratarata (mean) \pm SE. Data dianalisis secara statistik dengan ANOVA satu jalan dan dilanjutkan dengan uji Tukey. Batas signifikansi statistik ditetapkan pada $\mathrm{P}<0,05$.

\section{Hasil dan Pembahasan}

Pengumpulan Sampel Tumbuhan dan Pembuatan Serbuk Simplisia Kering

Sampel basah kayu batang simpur diperoleh dari Jalan Panglima Aim daerah Pontianak Timur. Tumbuhan simpur dipisahkan antara batang, daun, dan bunga. Kayu batang simpur dipotong, dicuci, lalu dikeringanginkan. Kayu batang simpur yang telah kering, diserbuk menggunakan mesin penggiling dan diperoleh serbuk kayu batang simpur sebanyak $11,5 \mathrm{~kg}$.

Hasil Ekstraksi Kayu Batang Simpur

Ekstraksi 6 kg serbuk kayu batang simpur dilakukan menggunakan teknik maserasi selama $3 \times 72$ jam dengan $27 \mathrm{~L}$ pelarut etanol. Ekstrak kental yang diperoleh sebanyak 87,9 gram $(1,47 \%$ rendemen ekstrak etanol yang didapat). Efek Ekstrak Etanol Kayu Batang Simpur terhadap Berat Badan Tikus

Berdasarkan hasil penelitian, rata-rata berat badan tikus di setiap kelompok selama 28 hari ditunjukkan pada Gambar 1. Berat badan tikus antar kelompok pada hari ke-0 sampai ke-28 menunjukkan tidak berbeda nyata. Kelompok kontrol negatif (diabetes) cenderung mengalami penurunan berat badan sedangkan kelompok perlakuan baik dengan glibenklamid maupun ekstrak etanol kayu batang simpur cenderung mengalami peningkatan berat badan. Peningkatan berat badan tikus pada kelompok tikus diabetes yang diberi ekstrak etanol kayu batang simpur 
tidak berbeda nyata dengan kelompok normal maupun glibenklamid, namun berbeda nyata dengan kelompok tikus diabetes (kontrol negatif). Tidak ada perbedaan nyata antara kelompok tikus diabetes yang diberi ekstrak etanol kayu batang simpur dosis 150, 300 maupun $600 \mathrm{mg} / \mathrm{kg} \mathrm{BB}$.

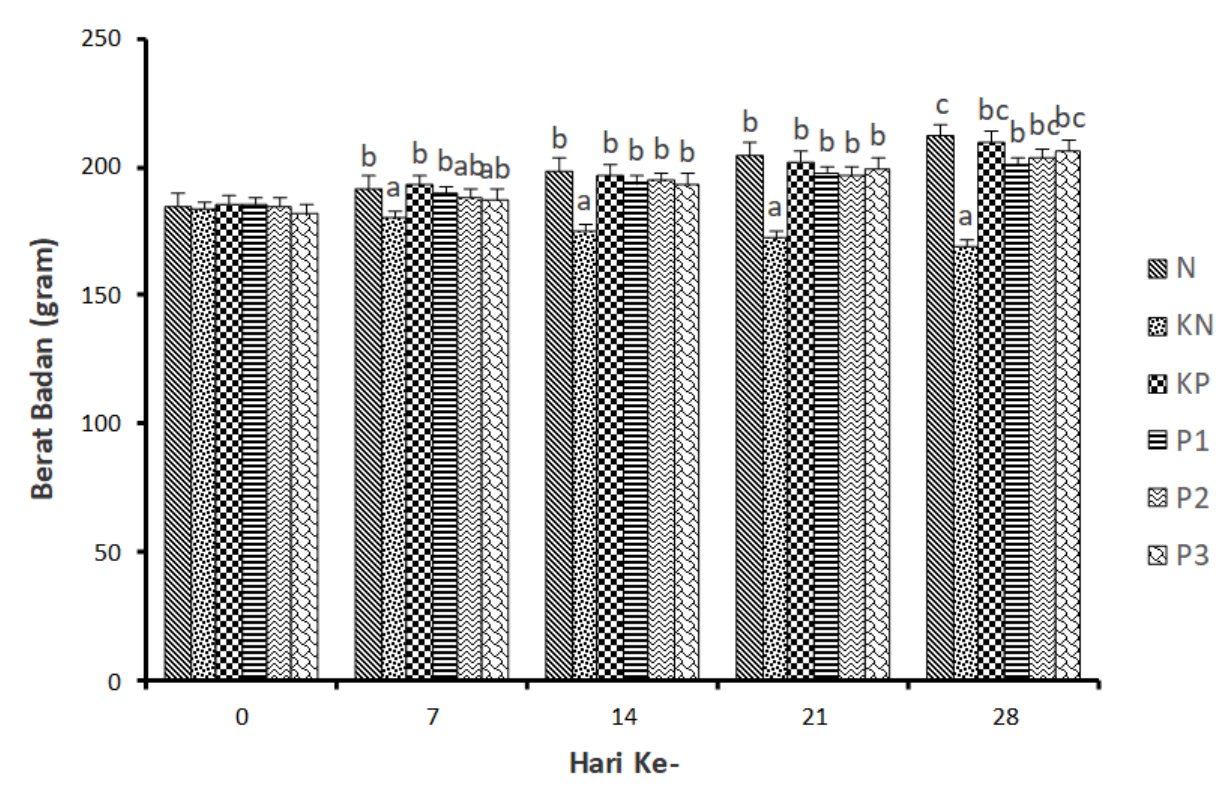

Gambar 1. Berat badan tikus selama 28 hari perlakuan. Data diekspresikan dengan rata-rata (mean) \pm SE. Induksi diabetes menggunakan STZ-NA (45, 110 $\mathrm{mg} / \mathrm{kg}$ ), KP dengan pemberian GLB 0,09 mg/200 g. Kelompok yang diikuti huruf yang sama berarti berbeda tidak nyata pada taraf $\alpha=0,05$.

Penurunan berat badan tikus karena penurunan hormon insulin yang diproduksi oleh sel $\beta$ pankreas tidak bekerja secara optimal untuk mengubah glukosa menjadi glikogen. Dengan demikian, glukosa tidak dapat diserap di dalam sel yang mengakibatkan tingginya kadar glukosa di dalam plasma darah. Karena tidak adanya gula yang diserap sel, maka energi yang digunakan untuk beraktivitas diperoleh dari respirasi menggunakan sisa-sisa gula yang tersimpan di otot dan dalam jangka waktu yang lama, gula tersebut akan menipis yang menyebabkan penurunan berat badan tikus. Peningkatan berat badan tikus diabetes yang diberikan glibenklamid dan ekstrak etanol kayu batang simpur dapat terjadi karena adanya perbaikan sel $\beta$ dan peningkatan sensitivitas reseptor insulin sel- $\beta$ pankreas sehingga hormon insulin dapat bekerja secara optimal.

Efek Ekstrak Etanol Kayu Batang Simpur terhadap Kadar Glukosa Darah

Untuk mengetahui pengaruh ekstrak etanol kayu batang simpur terhadap kadar glukosa darah, maka 
dilakukan uji ANOVA satu jalan yang dilanjutkan dengan uji Tukey. Hasil uji ANOVA satu jalan menunjukkan bahwa ekstrak etanol kayu batang simpur berpengaruh secara nyata terhadap kadar glukosa darah tikus yang diinduksi streptozotosin-nikotinamid $(p<0,05)$. Uji lanjut dengan Tukey menunjukkan bahwa terdapat perbedaan yang nyata antara kelompok tikus diabetes dan kelompok yang diberi glibenklamid dan ekstrak etanol. Serta kelompok yang dilakukan pemberian ekstrak etanol kayu batang simpur dengan dosis $600 \mathrm{mg} / \mathrm{kg}$ BB tidak berbeda nyata dengan kelompok kontrol positif (diabetes+glibenklamid).

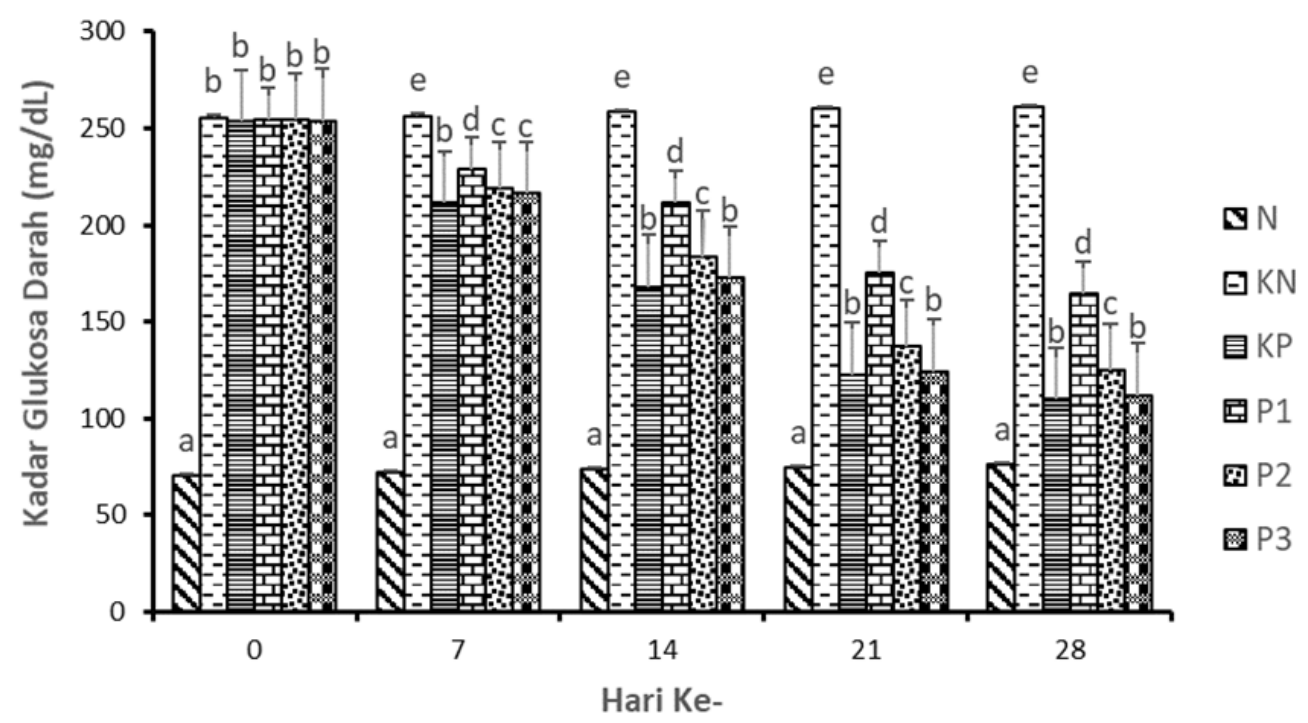

Gambar 2. Kadar glukosa darah tikus selama 28 hari perlakuan. Data diekspresikan dengan rata-rata (mean) \pm SE. Induksi diabetes menggunakan STZ-NA (45, $110 \mathrm{mg} / \mathrm{kg}$ ), KP dengan pemberian GLB 0,09 mg/200 g. Kelompok yang diikuti huruf yang sama berarti berbeda tidak nyata pada taraf $\alpha=0,05$.

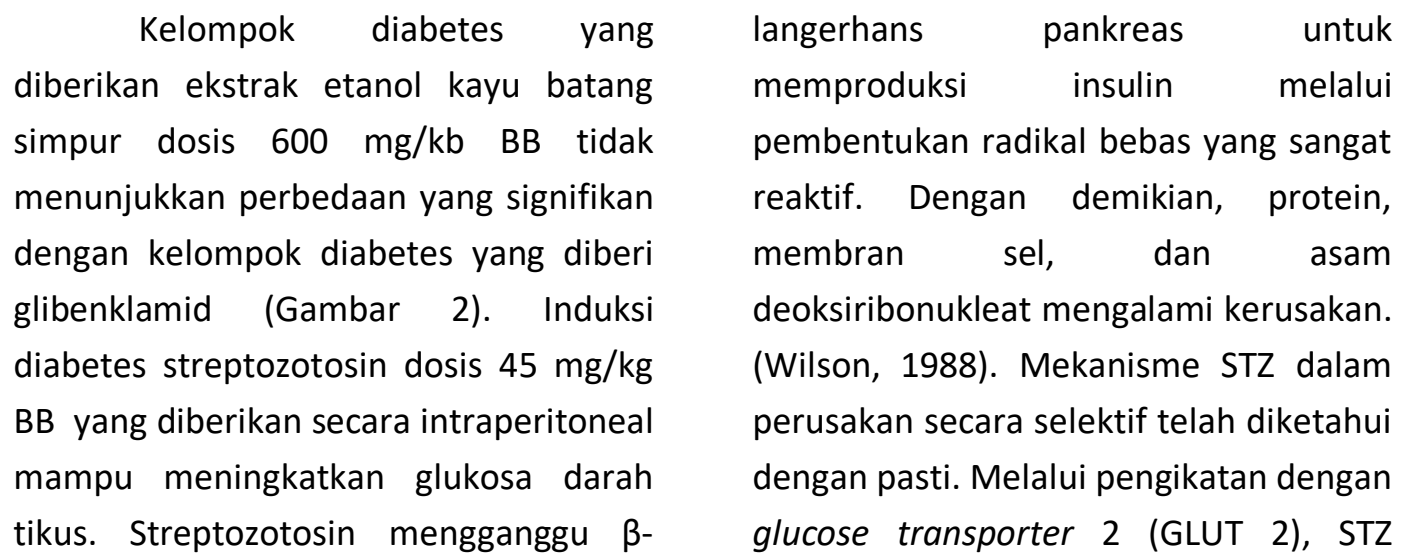


dapat masuk ke sitoplasma $\beta$ pankreas, sehingga depolarisasi pada mitokondria mengalami peningkatan dengan masuknya ion $\mathrm{Ca}^{2+}$. Produksi insulin mengalami gangguan sehingga terjadi defisiensi insulin. Kadar glukosa mengalami peningkatan karena glukosa yang ada dalam tubuh tidak dapat diolah secara sempurna (Greenspan, 1998). Penambahan nikotinamid berperan dalam melindungi sel $\beta$ pankreas dari kerusakan secara berlebih. Nikotinamid merupakan antioksidan turunan vitamin B3 (Niasin) yang melindungi sel beta pankreas dari aksi sitotoksik streptozotosin dengan beberapa mekanisme (Ghasemi et al., 2014).

Pemberian glibenklamid dan ekstrak etanol kayu batang simpur dosis 150, 300, dan $600 \mathrm{mg} / \mathrm{kg}$ BB mampu menurunkan kadar glukosa darah. Penurunan kadar glukosa darah terjadi setelah pemberian glibenklamid dan ekstrak etanol kayu batang simpur dengan dosis 150,300 , dan $600 \mathrm{mg} / \mathrm{kg}$ BB. Glibenklamid dan ekstrak etanol kayu batang simpur dosis $600 \mathrm{mg} / \mathrm{kg} \mathrm{BB}$ memiliki kemampuan yang sama dalam menurunkan kadar glukosa darah tikus diabetes.

Glibenklamid merupakan salah satu obat diabetes mellitus tipe 2 dari golongan sulfonilurea. Glibenklamid yang digunakan dalam bentuk terapi tunggal maupun kombinasi mampu menurunkan secara efisien glukosa darah (Duppala et al., 2013). Selain itu, menurut Soegondo (2009), sulfonilurea bekerja dengan memicu produksi hormon insulin oleh sel $\beta$ pankreas.
Ekstrak etanol kayu batang simpur mampu mereduksi kadar glukosa darah melalui penghambatan enzim $\alpha$ glukosidase dan radikal bebas (Masriani, 2018). Enzim $\alpha$-glukosidase berfungsi untuk menguraikan karbohidrat (polisakarida) menjadi glukosa (monosakarida), sehingga dengan adanya penghambatan enzim ini maka akan dapat mengurangi kandungan glukosa di dalam darah, hal ini diperkuat oleh hasil penelitian Muharini (2018) yang menunjukkan bahwa ekstrak etanol kayu batang simpur memiliki sifat antioksidan dari senyawa metabolit sekunder yang tergolong flavonoid dan fenolik, penghambatan radikal bebas dapat mengurangi stres oksidatif. Berkurangnya stres oksidatif dapat mengurangi resistensi insulin dan mencegah perkembangan disfungsi dan kerusakan sel $\beta$ pancreas.

\section{Simpulan}

Ekstrak etanol kayu batang simpur dengan dosis $600 \mathrm{mg} / \mathrm{kg}$ BB efektif menurunkan kadar glukosa darah tikus diabetes yang diinduksi streptozotosin-nikotinamid.

\section{Daftar Pustaka}

Campbell, I. 2007. Oral antidiabetic drugs: their properties and recommended use. Prescriber, 18(6):56-74.

Duppala, V., Dash, R.P., Jivrajani, M.N., Thakur, S.K., Ravat, N.M., Nivsarkar, $\quad$ M. 2013. Simultaneous quantification of glibenclamide, simvastatin, and 
quercetin by using LC-UV method and its application to pharmacokinetic study in rats. Chromatography Research International, 2013:Article ID 768160 .

Ghasemi, A., Khalifi, S., Jedi, S. 2014. Streptozotocin-nicotinamideinduced rat model of type 2 diabetes. Acta Physiologica Hungarica, 101(4):408-420.

Greenspan, F.S. 1998. Endokrinologi Dasar dan Klinik. Edisi 4. Jakarta: EGC.

Gupta, R., Bajpai, G.K., Johri, S., Saxena, A.M. 2008. An overview of Indian novel traditional medicinal plants with antidiabetic potentials. African Journal of Traditional, Complementary and Alternative Medicine, 5(1):1-17.

International Diabetes Federation (IDF). 2011. Diabetes Atlas. $5^{\text {th }}$ Edition. Brussels: IDF.

Masriani, 2018. Aktivitas penghambatan a-glukosidase ekstrak etanol tumbuhan simpur (Dillenia suffruticosa) dan sengkubak (Pycnarrhena cauliflora). Laporan Penelitian DIPA PNBP FKIP 2018.

Rias, Y.A. 2017. Hubungan antara berat badan dengan kadar gula darah acak pada tikus diabetes mellitus. Jurnal Wiyata, 4(1):7277.

Muharini, R. 2018. Pengujian fitokimia dan aktivitas antioksidan ekstrak kayu batang tumbuhan simpur air Dillenia suffruticosa. Laporan Penelitian Dana PNBP FKIP 2018.

Singha, A.K., Bhattacharjee, B., Ghosh, R., De, U., Maiti, D. 2013. Antibacterial, antialphaglucosidase, and antioxidant activity properties of Dillenia pentagyna Roxb (Dellinaceae). Asian Journal of Pharmaceutical and Clinical Research. 6:173-177.

Soegondo, S. 2009. Farmakoterapi pada pengendalian glikemia diabetes melitus tipe 2. Dalam IImu Penyakit Dalam. Editor Sudoyo A. W. Jilid III. Edisi 5. Jakarta: Penerbit FK UI.

Song Y.Q., Manson, J.E., Buring, J.E, Sesso, H.D., Liu, S. 2005. Association of dietary flavonoids with risk of type 2 diabetes, and markers of insulin resistance and systemic inflammation in women: a prospective study and cross-sectional analysis. Journal of the American College of Nutrition, 24:376-84.

Sukandar, E.Y., Adrajati, R., Sigit, J.I., Adnyana, I.K., Setiadi, A.A.P., Kusnandar. $2008 . \quad$ ISO Farmakoterapi. Jakarta: PT. ISFI Penerbitan.

Wilson, G.L. 1988. Mechanism of nitroroure induced beta cell damage: activation of poly (adpribose) syntase and cellular distribution. Diabetes, 37:213216.

[WHO] World Health Organization. 2016. Global Report on Diabetes France: WHO. 